\title{
THE LONDON “CRIMP” RIOTS OF 1794
}

Though in recent years there has been a growth of interest in the subject of riot and disorder in eighteenth century England, little attention has been paid to anti-recruiting riots. ${ }^{1}$ These were, however, one of the most common forms of riot and disturbance in some areas; and in this study of the London riots of 1794 I hope to illustrate some of their features, particularly in the London context.

The armed forces of England in the late eighteenth century were in the main composed of long service volunteers. In war-time the navy was also traditionally empowered to use the press-gang to take any men who had experience of the sea. When there was a great demand for sailors, then the traditional restraints might be cast aside, but such actions were on the whole exceptional. ${ }^{2}$ In contrast the army had no special powers reserved to it for use in war-time, the ranks of the army had to be filled in war, as in peace, by the recruiting parties. These recruiting parties had no equivalent to the powers of seizure enjoyed by the press-gangs; army recruits had to be pursuaded to volunteer and accept the "King's Shilling" after which they were legally bound to enlist. Cajolery, threats, and bribery were not unknown, but the army had to employ more subtle methods than the naval press-gangs. Both the army and the navy recruited with little in the way of government intervention. The press-gangs operated for their own ships and fleets, while the recruiting parties operated for the Colonels who raised and ran the regiments. The only branch of the armed forces raised systematically was the militia, which was selected by ballot amongst the inhabitants of each county. As substitutes were allowed, these tended to be obtained in the same way as the recruits for the regular services, by the offer of a bounty or simply of escape from civilian life. ${ }^{3}$

The principal obstacle to recruiting a full complement of men in the

1 There is a discussion of riots against the Militia in J. R. Western, The English Militia in the Eighteenth Century (1965), pp. 290-303.

2 There is an excellent account of the use of the press in C. Lloyd, The British Seaman (1968), especially chapters seven and eight.

3 J. R. Western, op. cit., pp. 245-264. 
various branches af the armed forces was their unpopularity. The navy managed to retain some degree of popular favour, probably because it was quartered out of contact with the mass of the inhabitants. Though wages were lower than in the army, discipline was less severe, at least in theory, and service more varied. ${ }^{1}$ In the last resort the press-gang could be relied upon to fill the ranks of the navy in time of war. The army was regarded with rather less favour, not only on constitutional grounds, but also because of the army's bad reputation for indiscipline and the lawlessness. Successive acts, such as those of 1703 and 1779, drafted paupers, debtors, and criminals into the army with the inevitable result that the prestige of the army was lowered. As one recent historian of the English army in the Napoleonic period has remarked: "The army was a midden fit only for outcasts, and the red coat was a badge less of honour than of shame."2 Pay in the army was low and discipline was severe. Moreover the army was the effective police force, frequently being called out to suppress riots and disorders. In London the memory was fresh in the seventeen-nineties of the Gordon Riots of 1780 , when the mob had been repelled by the volleyfire of the troops. And while this extreme example had taught the London mob to regard the army as its natural enemy, it had not made Whig opinon in the capital any the more ready to look with favour on the use of the troops within the City of London.

It was, however, on the lower classes of the capital that most of the burden of recruiting for the armed forces tended to fall. The size and concentration of population in London provided unparalleled opportunities for recruiting for all branches of the armed forces. Press-gangs operated widely in the dock-land and river-side areas of the capital when fleets were being manned for service; as a result there were numerous battles between press-gangs and local inhabitants. ${ }^{3}$ Recruiting centres for army, navy, and militia were known as "rendezvous houses", usually set up in a conveniently sited alehouse. There were a large number permanently established in the capital and at the outbreak of hostilities the number was increased. Most of them had some form of strong-room to secure unruly recruits; but though regarded with suspicion, they were at least openly recognisable as recruiting centres and usually displayed a flag or posters. Much more disliked were the "crimp" houses; "crimps" were agents who traded in recruits when men were in great demand either for the armed forces or to man

1 C. Lloyd, op. cit., chapter eleven.

2 M. Howard, Studies in War and Peace (1970), p. 51.

3 Using newspaper sources, I have been able to discover about twenty riots or affrays in London caused by the activities of the press-gangs between 1790 and 1800 . 
merchant vessels on the point of sailing. They made their profit from the bounty or reward offered in times of scarcity to recruits who came forward. Men who were short of money would surrender themselves into the hands of the "crimps" to pay off their creditors. Sailors would often be induced by "crimps", operating from an alehouse, to run up expenses on credit, which they would be forced to redeem with the bounty from enlistment or the advance wages for a voyage. ${ }^{1}$ Others were simply decoyed by prostitutes and kidnapped. Francis Place wrote of the "crimp" houses: "In these houses the basest of villainies were practised. In most such houses there was a strong-room in which men who had been impressed or crimped were locked up, unlit, until they could be removed to the tender off the Tower or to the Savoy prison. They who were crimped were taken before a justice of the peace, a trading justice, and sworn in whether they consented or not. Men who had been pressed or crimped were usually handcuffed like felons and in this condition were marched through the streets." 2

The war against revolutionary France put an unprecedented strain upon the recruiting system. The navy was increased from 16,613 sailors in 1792 to 87,331 in $1794 .^{3}$ The regular army was enlarged by thirty regiments of foot and several regiments of cavalry. As a result there was an acute shortage of men and the bounties offered to army recruits rose as high as thirty pounds. The situation was one in which the "crimps" flourished, as the New Annual Register noted: "One of the great evils of war is the encouragement given to deceit, fraud and cruelty in procuring recruits for the service. When the war is itself unpopular, the bounties to recruits rise in proportion to the general reluctance to enlist. When the bounty money is at the highest the more extensive and subtle is the system of turning it to account through all the subordinate gradations of the military brokers. The recruiting houses in London, kept by crimps and kidnappers, were the general scenes of enormities committed in this atrocious and inhuman traffic. Debauchery and intoxication, the general means of seduction into the engagement; force, cruelty and sometimes perjury, the remedy against repentance in the moment of returning sobriety and reflection; these evils will ever exist as long as the present recruiting system is continued."4

A number of rumours about men being kidnapped in this way passed into common circulation in the summer of 1794 . These rumours

1 There is a description of their methods in W. Connor Sydney, The Early Days of the Nineteenth Century (1898), pp. 134-6.

2 Place papers, British Museum, Add. Mss 35142, ff. 8-9.

3 C. Lloyd, op. cit., p. 263.

4 The New Annual Register, 1794, pp. 264-6. 
seemed confirmed in the case of Edward Barrett whose case was examined at the Bow Street Police Office. Barrett, a discharged sailor, claimed that he had been decoyed into the White Horse, Whitcomb Street, where he was at first given drink and then imprisoned in the garret of the public house for a fortnight, during which time he was starved and robbed. He was eventually put in a cart and taken to a regiment at Banbury, where he was able to interest the Mayor in his story and eventually return to London. The warrants to arrest the owners of the White Horse did little to appease growing popular anger. ${ }^{1}$

The "crimp" houses were not the only reason for dislike of the armed forces and service therein. The City of London was in the process of balloting for its newly reorganised militia in the summer of 1794. There was much popular unrest at the use of a ballot, as it was felt that the persons balloted would have to buy a substitute and that it would have been better to levy a general rate on each Ward of the City to provide the money to buy the full quota of substitutes. The provisions of the Bill that had passed through Parliament meant that a heavy burden was being placed on those balloted. Amidst widespread expressions of anger and opposition the balloting went on. An appeals day was set for those who opposed having been balloted, but it was firmly stated that no appeals would be heard after that day, the 19th August. ${ }^{2}$

Thus in mid-August, 1794, there was considerable opposition and popular anger in London towards two aspects of the recruiting system. Some sections of the Whig party had attacked the London Militia Bill as part of an anti-war campaign. The Whig-inclined New Annual Register attacked the Bill, describing it as "a link of that chain of innovation on the rights of the people which characterised the present administration, and another attempt to convert the government of the country into an absolute monarchy and introduce a military government." 3 This attitude on the part of some sections of the Whigs added fuel to popular anger in the capital against the recruiting system and the war in general. Moreover the anti-war feeling of the radical societies was well-known, with their insistance on following the example set by France.

On the 15th August in Johnson's Court, Charing Cross, a young man named George Howe was taken to the King's Arms recruiting house. The area and that court in particular was known as one "notorious for

I The Courier, 19th July, 1794.

2 The City of London Court of Lieutenancy Minute Book for July 1794, Guildhall Library, London.

3 The New Annual Register, 1794, pp. 252-3. 
disorderly and alarming scenes of debauchery and cruelty". A Mrs Hannah kept six recruiting houses there which, it was claimed, were "contiguous and communicated by secret passages to one another". Howe, who was later declared insane, seems to have been put in the attic with his hands tied. At about 2p.m. he was found dead on the ground outside the house with his hands still tied and presumably having tried to escape. A crowd gathered and a justice arrived. The justice was none other than Sheridan, a prominent member of the Whig opposition, who was thus in a position to embarrass the government over the "crimp" houses. He signed a warrant for the search of neighbouring "crimp" houses, particularly one belonging to one Jacques Layzell. This search was only reported in the opposition press and it was claimed that a man dying of small-pox was found chained in a tiny cell. As the mob was growing larger and more restive the Horse Guards were called in to disperse them. On the next day an inquest on Howe said that he had been killed while attempting to escape from a house of "ill-fame". Sheridan went immediately to the Bow Street Office, demanding that a search be made of all recruiting houses. $\mathrm{He}$ was refused, but nonetheless Sheridan signed a warrant for the arrest of Layzell. ${ }^{1} \mathrm{He}$ was now overtaken by the fury of the London mob.

On Saturday night and early Sunday morning a great crowd collected at the King's Arms, Craig Street, belonging to William Oastliff, and other recruiting houses near Charing Cross. Though the Foot Guards remained there and cavalry were added, the crowd continued to collect. Five boys were reported taken in custody to St Martin's Watch-house and were examined at Bow Street, before being committed to Tothill Fields for the next Westminster sessions. ${ }^{2}$ There were also reports of rumours of passages to the Thames and of men being sent off through them at night. At the Home Office the chief preoccupation was to get a magistrate to Johnson's Court in the late afternoon. ${ }^{3}$ Earlier in the afternoon the Home Office received a report from Kirby of an attack on the Bull in Petty France and of threats to burn it down. ${ }^{4}$ At 6p.m. Staples of the Shadwell Public Office reported that he had seized "three capital Sans Culottes". ${ }^{\mathbf{5}}$

On Monday the 18th the Court of Lieutenancy was duly held in the Guildhall to hear the appeals under the provisions of the Militia Bill. It was reported that several thousands assembled and that the cry was

1 The New Annual Register, 1794, pp. 264-6.

2 London Packet, 18th August, 1794.

${ }^{3}$ J. King (Home Office) to ? (no address), 16th August, 1794, Public Record Office, HO 42.33 .

4 Kirby to Home Office, 16th August, 1794, HO 42.33 .

5 Staples to Home Office, 16th August, 1794, HO 42.33. 
raised of "Down with the Recruiting Houses". The Mayor, unable to deal with the enraged throng ordered the populace back to their own wards for the appeals to be heard. ${ }^{1}$ The St. James Chronicle commented on the occasion that: "Many infamous attempts have been made by false and iniquitous inflammatory handbills and pamphlets to prejudice the minds of the people." The Court of Lieutenancy and the Mayor were accused of having "smuggled" the Militia Bill through without proper consultation. ${ }^{2}$ In this way the anti-crimp feelings of the populace were linked with the Militia Bill issue; the first accusations of attempts to start the riots by interested parties had also been made. While the accusations flew around, the riots carried on. On Tuesday it was reported that handbills were being put out which said that men were being kidnapped and sent to Canada and elsewhere. ${ }^{3}$ The mob attacked the White Horse public house in Whitcomb Street. ${ }^{4}$ Some boys were reported to have taken a bed out of the Shoe Lane crimp house and ripped it up. ${ }^{5}$ There also occurred the first of a series of complaints about the behaviour of the troops when it was claimed that the Horse Guards had trampled on people on their way to the riots. ${ }^{6}$ At 2p.m. on the 20th information was given to the Mayor of a riot beginning in Shoe Lane. The constables were sent and found in nearby Stonecutter Street "a mixed multitude of men, women, boys and children here assembled, who though not at that moment in the act of rioting were very disorderly and troublesome". The Mayor reported: "Finding that other houses of rendezvous were threatened, and finding the impossibility of quelling a further riot with the civil power only, I returned at five to the Mansion House and there sent to the commanding officer of the Light Horse Volunteers to request that he should collect as many of his corps as he could order and proceed to Fleet Street." The Mayor also sent for the Artillery Company to come at once to Shoe Lane with 12 rounds of ball cartridge and to the Tower for 100 men. When the Mayor returned he found that the crowd was more formidable and even with 100 constables he feared he would be unable to clear the streets. The Mayor also learnt for certain that the intention of the rioters was "to pull down every house which had been opened as a House of Rendezvous" and houses elsewhere were positively mentioned as being marked out. ${ }^{7}$

1 Gentleman's Magazine, August 1794.

2 St. James's Chronicle, 29th August, 1794.

3 St. James's Chronicle, 23rd August, 1794.

4 Gentleman's Magazine, op. cit.

5 London Packet, 19th-21st August, 1794.

- General Evening Post, 19th-21st August, 1794.

7 Lord Mayor to Duke of Portland, 21st August, 1794, HO 42.33. 
At 7.30p.m. as some Coldstream Guards were approaching the area the Mayor read the Riot Act, but the people refused to disperse until the act was read three more times and the Mayor commanded the soldiers to clear the streets. 40 men of the Artillery Company were sent to the eastern part of the city. Between 8p.m. and 9p.m. there was news of a mob in Holborn attempting to break into the Bull public house, belonging to Robert Layzell. The mob was in the act of firing the house when the Mayor and his men arrived; the Riot Act was read and some of the rioters seized. ${ }^{1}$ Richard Hollier, the Marshal sent from Shoe Lane by the Mayor, said 500 people were there, breaking the doors, windows and frames of the house; Layzell later estimated the crowd to have been between 200 and $400 .^{2}$ The Mayor claimed that after reading the Riot Act again the crowd were quiet. The Mayor then heard of a mob in Bride Lane, pulling down a house, but could not leave the Holborn crowd. He therefore waited for the arrival of the Light Horse Volunteers and sent them to deal with the Holborn mob before going himself to Bride Lane. When he arrived he heard that the mob had gone on to Long Lane, where he missed them again, for as he put it "they were too nimble for us and after having gutted that house they went to Golden Lane, which being out of my jurisdiction I desired Capt. Herries of the Light Horse Volunteers who had come with twelve of his Corps to follow them." The Mayor later learned that Capt. Herries followed the rioters to Moorfields where his men dismounted and seized five of the rioters. ${ }^{3}$

At Golden Lane Luke Case, the proprietor of the Black Raven, was warned about 10p.m. by some women to leave his house. He testified to there being 100 or so in the mob, which was driven off only after his windows had been pulled down, his house entered by 20 or more of the mob, his furniture smashed and some drink and candles stolen. At the Sash public house of Middle Moorfields, John Wheeler at 10.30p.m. was warned by the constable that rioters were on the way. 20 or so arrived at first and one asked Wheeler whether his house was a crimp. Whatever the outcome of this conversation, fifteen minutes later about 200 people arrived and wrecked his furniture and broke into the cellar. ${ }^{4}$ The mob then went to Whitecross Street before retiring about 2a.m. The mob in Fleet Street during the day was said to be uncommonly violent. The cry was repeated of "No War - No Soldiers", "Liberty and no Crimps". The General Evening Post also commented that: "The spirit of mobbing can only be prevented by demonstrating to the

1 Lord Mayor to Duke of Portland, 21st August, 1794, HO 42.33.

2 Old Bailey Proceedings for 1794, pp. 955-995.

3 Lord Mayor to Duke of Portland, 21st August, 1794, HO 42.33.

4 Old Bailey Proceedings, op. cit. 
people that the oppression of which they complain is not overlooked. They are rarely found deficient in respect to the laws and submission to their superiors, when they find that the former are properly enforced and that the latter are not inattentive to their complaints." 1

Unfortunately the authorities themselves had little faith in the efficacy of such assurances. One man was put in prison for saying: "These kidnapping houses ought to be pulled down; if the people could get these swords out of the armourers' shop, the military should see what they could do."2 By Wednesday the authorities were beginning to deal with the arrests of the previous two days. Several of the persons concerned in the riot and destruction of the Whitcomb Street public house on Tuesday evening were examined before the magistrates at the Police Office in Bow Street, where one Richard Bramley of the Victualling Office was committed to Newgate on a capital offence, having incited the mob after the reading of the Riot Act. Others were charged with disorderly behaviour. In Duke Street off Oxford Road a mob had beaten up a waiter whom they suspected of crimping. Several men were taken into custody for riotously assembling at the house of $\mathrm{Mr}$ Boss in Shoe Lane and were sent to the New Compter. A house in Drury Lane near Bennet's Court was also attacked and the Foot Guards drove the mob off. ${ }^{3}$

The Home Office was deluged by advice from various quarters. $\mathrm{Mr}$ Devagnes wrote to the Home Office from the East India House that he feared that the attacks would end the recruiting service for: "It would be very desirable that mobs of this description should be dispersed without military interference, for should the soldiers and the mob come to blows it is to be feared the mischief would soon extend itself especially if there are evil disposed ready to make use of the prejudices and passions of the common people to serve their own purposes." He suggested that self-defence associations should publish a hand-bill, putting forward the "evil consequences" of the riot and undertaking that if there were any real cause of complaint against the owners of the houses the committee would examine into the causes of it. The Associations could also come together to induce mobs to disperse. Moreover with so many magistrates absent in the country, he offered to put it into practice in St James if that was agreed to. ${ }^{4}$ The Home Office replied that they doubted whether there would be any hope of the bills having effect. Several of the hand-bills from the past days were sent in.

1 General Evening Post, 19th-21st August, 1794.

2 General Evening Post, 23rd August, 1794.

3 London Packet, 22nd August, 1794.

4 Mr Devagnes to Home Office, 20th August, 1794, HO 42.33. 
The night of the 20th to the 21st was much disturbed. Patrick Colquhoun wrote to Nepean at midnight that a "most desperate mob" had pulled down three houses. He was certain that only recruiting houses had so far been pulled down and he remarked on the "astonishing rapidity" with which the mob was moving. He went on to say that the military associations of Hackney and Tower Hamlets were not yet ready and that when it was considered "that the chief part of that class of low people who are likely to strengthen a mob reside in this part of the metropolis", it was necessary to strengthen the civil power. He reported that the mob had moved out to Cock Lane in Spitalfields and to Rosemary Lane in Wapping and that armed men were required. ${ }^{1}$ At 1.00a.m. he wrote to the Duke of Portland an urgent note in which he said that without military assistance the civil power could not deal with the mob as the armed associations were not expected for some time. Moreover he voiced his suspicions on the origins of the riots: "I have strong grounds to believe that these riots have been excited by the leaders of the seditious societies whose views extend very far beyond the recruiting houses." 2

The Mayor put out a hand-bill to keep children and servants off the streets. The associations, special constables and six county regiments all stood by ready to move into the City. Arms that lay in the warehouses of the East India Company were directed to be deposited in the Tower. Moreover the churchwardens were instructed by the Home Office to call special vestries for the purpose of swearing in special constables and taking such measures as should be required. The magistrates were informed of the stations that the cavalry would take up that evening and were sent copies of the act of George I dealing with riots. Magistrates in the country were requested to return as soon as possible. ${ }^{3}$

The activities of the mob continued and attacks were made on the constables in Bride Lane and Shoe Lane at 9 or $10 \mathrm{a} . \mathrm{m}$. by mobs armed with sticks from the Fleet market. The Associations of St John and St Margaret were called out and the mob again began to assemble. Nine of them were arrested and put in the New Compter and charged with assembling at the house of Mr Boss and trying to demolish it. Six were taken to Worship Street for the attack on the Sash House. There was no more trouble until 10.00p.m. when there was a report of a mob in Shoe Lane, pressing the Light Horse Volunteers with bludgeons and stones. The rioters were then faced by reinforcements and fled

1 P. Colquhoun to Nepean, 21st August, 1794, HO 42.33.

2 P. Colquhoun to the Duke of Portland, 21st August, 1794, HO 42.33.

3 King to Public Offices, 21st August, 1794, HO 43.5, and Gentleman's Magazine, op. cit. 
from the City, on the way attacking a building in Gray's Inn Lane. ${ }^{1}$ There was also a report of an attempt to start a riot on the night of the 21st in St George's Fields at the Milk House, on the corner of the London Road, where a sergeant recruited for the Volunteers, but this was beaten off. The St. James Chronicle said of this attack: "that it was evidently apparent that the mob was led on by persons above the common rank, whose sole aim is, if possible, under the idea of some pretended grievance to raise a general riot in the metropolis ..... As some persons in those mobs frequently cry out 'Liberty, Fraternity and peace with France' it is an easy matter to conjecture by what party they are encouraged thus illegally to assemble and wantonly insult the law and constitution of their country. It is greatly to be apprehended that there exists a scheme to raise mobs and disturb the peace of the metropolis." 2

The Lord Mayor reported to the Duke of Portland that all day on the 21 st the City and its environs were filled with continued reports of threats and menaces from the rioters which were brought to him by many respectable men on whom he said they had made a great impression. The Mayor told them that he considered the alarms as fabricated by a small party of "designing men, solely with a view to terrify, harras and perplex the magistrates". He had therefore sent for a detachment of His Majesty's Guards from the Tower and put 100 men of the Artillery Company at the Mansion House ready-mounted and armed. All was in fact quiet to 10.00 p.m. before which the Mayor dismissed the Guards. The Mayor paid a tribute to "their gallant, steady and orderly conduct" and assured the Duke "that there appears throughout this City a just abhorrence of the present attempts to renew the riots of 1780". The Mayor promised that an example would be made of the rioters if they came again that night. ${ }^{3}$

The morning of Friday promised a new kind of trouble for there was a public meeting called by bills at Founders' Hall, Lothbury to discuss and appeal from the Militia Act. The Mayor banned the meeting and the crowd dispersed. ${ }^{4}$ On the night of the 22 nd a mob went to a house in Mutton Lane near Hatton Garden, but the Horse Guards prevented them from reaching it. At Battle Bridge a party of them consisting of 300 to 400 assembled at 9.00 p.m. and were dispersed by constables. ${ }^{5}$ By Friday night the situation was beginning to look better for the authorities as the balance of forces against the rioters was increasing

1 St. James's Chronicle, 20th August, 1794.

2 St. James's Chronicle, 23rd August, 1794.

3 Lord Mayor to King (10.30 a.m.), 22nd August, 1794, HO 42.33.

4 Lord Mayor to King (11.30 a.m.), 22nd August, 1794, HO 42.33.

st. James's Chronicle, 23rd August, 1794. 
all the time. ${ }^{1}$ Colquhoun had sworn in all the inhabitants around the Worship Street Office and had 30 soldiers from the Tower plus a troop of horse from Epping who had arrived at 4.00a.m. He said he would swear in another 1,000 constables if necessary; on the next day he reported that he had sworn in 500 "respectable householders". At 10.30a.m. the Mayor wrote to King at the Home Office concerning a rumour of armed workmen, coming to join the rioters. The Mayor was of the opinion that: "The armed lightermen did not appear and the story is one of the many industrious lies that the rioters have fabricated for the purpose of harrassing me - I had nothing else yesterday from morning to night. I now verily believe that we shall have warm work tonight, but as I now wish the crisis to come soon, I do not mean if I can help it to have the Guards before seven o'clock." With these men he expected to have enough forces to deal with the rioters. On hearing of the proposed Lothbury Hall meeting and the hand-bill advertising it he wrote, "I have no doubt that this handbill is the production of our old friends Eaton and Co. The meeting shall certainly not take place." He also asked that the Home Office would direct "some resolute magistrate to take command of the police in Hatton Garden as they are shamefully supine there, as I shall have the pleasure of mentioning to you when we are again quiet". ${ }^{3}$

The Mayor realised on Saturday morning that the crisis had in fact passed. At 11.30 on the Saturday morning he wrote to the Home Office with the news that there had been no serious trouble during the previous night and that he did not need the King's Guards further, though he would retain 12 or 15 for two days as well as 50 of the Artillery Company. He also was going to swear in more constables so that he could do without the military. He reported that the Founders' Hall meeting was stopped by the good behaviour of the neighbourhood without any help from him, "I understand Eaton and Co. were in the street, but passed a number of resolutions against putting the occupier of the house in the Compter." 4 The greatest alarm came from a series of fires in Saffron Hill, King Street, Holborn and Deptford. At 12.00 he heard that there had been an attempt to set on fire the quarters of the Light Horse Volunteers. The Home Office regarded these as the last resort of the rioters and the "disaffected" to destroy the houses of rendezvous secretly. ${ }^{5}$ Though the riots were in fact over, the authorities were kept busy by rumour of more troubles. They received a letter

1 No precise figures are available for the authorities.

2 P. Colquhoun to W. Wickham, 22th August, 1794, HO 42.33.

${ }^{3}$ Lord Mayor to King, 22nd August, 1794, HO 42.33.

4 Lord Mayor to King, 22nd August, 1794, HO 42.33.

5 King to Lord Mayor, 22nd August, 1794, HO 42.33. 
from one correspondent on the 23rd, suggesting that arms should be taken from the windows of shops as the mob had been overheard threatening to arm themselves. At Charing Cross it was said that the mob had broken a sword-cutter's windows, though there were no other reports of the mob arming themselves. ${ }^{1}$ On Sunday there was news that the journeymen hatmakers, shoemakers and farriers had struck work, but upon this the Mayor commented "whoever may have set them on this, it is too much in the interests of the masters to settle the dispute to doubt of its being made up."2

By Sunday various people began to feel that they were in possession of enough evidence to ascertain the cause of the riots. Patrick Colquhoun, who had been in the midst of some of the worst of the riots at the Worship Street Office, was of the opinion that the riots were premeditated. He said that the hand-bills which were circulated before the Charing Cross episodes led him to believe that agitators were at work. He went on: "I have strong grounds to believe that the riots are the result of a deliberate system originating with the corresponding societies for the purpose of introducing anarchy and confusion into the capital that they may with more ease carry into execution these designs which they are hatching for the purpose of overthrowing the government." It seemed to him that these societies were using the unpopularity of the crimps, and were circulating this idea through ballad singers, inflammatory papers and hand-bills, "the chief tendency of which seems to be to transfer the rage of the multitude from the crimps to the magistrates". In his letter Colquhoun included a handbill he had found in Grub Street, which seemed to indicate an attack on the police offices. ${ }^{3}$ The London Chronicle for the week-end reported that: "Every night since the commencement of the disturbances the mob has worn a more threatening aspect, they assemble early in the afternoon and by dusk appear in such numerous bodies as there is no resisting by means of the civil power and even the military are at a loss how to act against an enemy so widely scattered and seemingly armed in the cause of humanity. However, we cannot help thinking that in the present business, more is meant than meets the ear, well assured as we are, in consequence of the most minute enquiry that many of the narratives which have had such an effect upon the passions of the populace (a great part of whom, perhaps, at first were activated by a well-meaning zeal) were totally unfounded."4

1 Information to King, 22nd August, 1794, HO 42.33.

2 Lord Mayor to King (5.00 p.m.), 24th August, 1794, HO 42.33.

3 P. Colquhoun to King, 22nd August, 1794, HO 42.33.

- London Chronicle, 21st-23rd August, 1794. 
That there had been an attempt to stir up disorder seemed evident to the Home Office, for there were a series of hand-bills passed around during the disturbances. Mr Churchill, a surgeon, sent in a paper to the Home Office which he had found in the street on the 18th, sealed up like a letter. ${ }^{1}$ The evidence of the hand-bills suggested that there had been an attempt to stir up trouble in anticipation of the day of appeal against selection for the London Militia. At the meeting on the appeals day it was obvious that some sections of the crowd had linked the two issues of the crimps and the militia balloting. In the hand-bills the issues were also linked and formed a coherent anti-military, antiwar, and anti-ministerial platform. To the authorities it was obvious that the radical societies were planning an all out attack on the forces of order, using the anger of the populace at the recruiting system. The hand-bills were obviously well-printed and also fairly widely distributed. Moreover to confirm the fears of the authorities they had caught at least one man whom Patrick Colquhoun described as a "great Jacobin" and a member of the radical societies. This was a man called Abraham Taylor, a cobbler, of Grub Street. On his stall were found pasted a number of inflammatory bills and others were concealed within it. The Churchwarden of St Luke's brought in one hand-bill entitled "Beware Britons", which Colquhoun regarded as clear evidence of the complicity of the radical societies for: "On the 8th instant when this paper was circulated there was not any riot at Charing Cross. The plan was hatched some time before and that house selected for the purpose of making a beginning. It was clearly a premeditated thing and not an accident as was supposed."2

This evidence was supported in a more circumstantial sense by what people had heard in rumour. A letter to the Home Office claimed to have heard "two genteel men" in Drury Lane say they belonged to a club of 5,000 members and would meet on Charing Cross to begin a general riot on Monday night. ${ }^{3}$ The admittedly partisan St. James Chronicle commented that: "On Friday and Saturday during the riots at Charing Cross great pains were taken to pursuade the people that there were subterranean passages from the houses to the Thames and that men were sent off in the night. On Monday and Tuesday night hand-bills were distributed telling the people that men and children were kidnapped and sent off to Canada and elsewhere."4

The nearest evidence to an attempt to attack the magistrates as

1 Churchill to Dundas, 19th August, 1794, HO 42.33 .

2 P. Colquhoun to W. Wickham, 22nd August, 1794, HO 42.33.

3 J. Heather to King, 20th August, 1794, HO 42.33.

4 St. James's Chronicle, 23rd August, 1794. 
opposed to the crimp houses comes from the bill Colquhoun sent in. This was a rough piece of paper with a very rough handwritten message which ran: "Southam Charles Sq. and Short, No. 32 Craven St., Hoxton. Informers Spies and Agents to Mr. Justice Colquhoun Charles Square Hoxton. Countrymen! If you would avoid the Bastile presume not to speak out your grievances or be deemed a Jacobin. ${ }^{\text {" }}$

Even this mooted an attack on the informers rather than the magistrate, though it does make it clear that Colquhoun was a marked man. Yet this seems a genuine riot notice manufactured in the heat of the riots, whereas the other ones were far more polished and carefully printed. The most common was one which ran: "Beware Britons of the hordes of crimps and kidnappers that infest the metropolis and its environs, who rot and imprison its peaceful inhabitants. Oh! think of the number of parents that are made wretched, in having their blooming sons torn from them by these Monsters - Would such atrocious acts have been suffered in the days of Alfred? If you bring the Demons before the magistrates you cannot get redress, they will screen them in defiance of the law. Is this the land so famed for liberty? Did Sidney and Russell bleed for this? - Oh my Poor Country!"2

This appeal to the Whig martyrs and the Days of Alfred seems to confirm the suspicions of the earlier commentators that this was an opposition inspired work. The two men who were later tried for conspiracy on this charge of distributing these bills also gave out one which attacked the Militia Bill: "For Shame! Awake from your lethargy! let it not be said of you that you used to animate the City of London in the preservation of their rights and liberties. If you do not resist with spirit the present innovation of those rights you will merit this or any other oppression that unprincipled or interested men in power may wish pto impose on you." 3 Another ran: "Consider, therefore, that it is absolutely contrary to the charter of the great City of London, which is that the said citizens shall not be sent to war without the City of London."4

This fusion of the old Wilkite issue of the City liberties, the militia bill and the crimp issue, coming from the same source, looks like an attempt to unite various interests into an anti-war platform. They were not averse to an appeal to the soldiers to refuse to fire on the crowd and this carries implications beyond a mere demonstration of anti-war action. "Soldiers, now is the time to acquire glory, protect

1 Inclosure of P. Colquhoun to King, 22nd August, 1794, HO 42.33.

2 Inclosure of Churchwarden of St Lukes to King, 22nd August, 1794, HO 42.33.

3 Old Bailey Proceedings for 1794, pp. 1326-50.

- Ibid. 
villainy, and murder those of your fellow creatures who have the courage to resist you." 1

But beyond the suspicions of the magistrates and the presence of the hand-bills, there is little evidence to substantiate the view that the riots were planned, either by the radical sections of the Whigs or the radical societies. Hand-bills could be prepared in a short space of time to capitalise on the disorders. While these did reveal a selfconscious desire to emulate the French example, it is only reasonable to question their possible influence on the situation. It is impossible to make any precise estimation of how many people could read these hand-bills and be influenced by them. ${ }^{2}$

The hand-bills were only fuel to a fire that was already raging. Popular fear and anger only required some incident or some incitement to spark it off. The exaggerated rumours of kidnapping would suggest a mood of hysteria. The arbitrary nature of the press or the crimp gangs would seem to have been projected into fear of kidnapping, which often accompanies popular fear of murder, death, taxation or in this case recruitment. The idea of being stolen away in the night for some exotic destination is a primitive fear which had often been aroused against a hated group, in this case the army. ${ }^{3}$ Rumours tend to play an important part in the riot situation. The evidence is that few riots occur without rumours to incite, accompany and intensify the violence. ${ }^{4}$ Rumours predicting violence would seem to have been circulating even before Howe's death, for on the 14th August the Mayor wrote to the Duke of Portland "I find the rioters are going to begin very soon and several places are threatened." 5

The issue had divided the authorities as we have seen, with some sections hoping to use the issue of the "crimp" houses to their own advantage. The important feeling that the action was therefore legitimate on the part of the mob reinforced the idea of a popular justice being enacted on the wrong-doers in exactly the same way as the concept of a fair price was so often a feature of food riots in the late eighteenth century. This would account for the restraint shown by the mob towards the persons involved and their concentration on the destruction of property. The rioters seem only to have attacked the

1 Inclosure in W. King to J. King (Home Office), 19th August, 1794, HO 42.33.

2 The question of literacy is discussed in R. K. Webb, The British Working Class Reader, 1790-1848; R. D. Altick, The English Common Reader.

3 The kidnapping rumour often accompanyies periods of social strain, see N. J. Smelser, Theory of Collective Behaviour (1967), pp. 101-130.

4 G. W. Allport and L. Postman, The Psychology of Rumour (1947), p. 193, and recognised by G. Rude, The Crowd in History (1964), pp. 244-5.

5 Lord Mayor to the Duke of Portland, 14th August, 1794, HO 42.33. 
places they suspected of being "crimps". There were no cases of the kind of orgy of looting and drunkenness that had accompanied the Gordon Riots and the crowd generated its own leaders, objectives and standards of behaviour within a few hours. This pattern of behaviour bears out the evidence on English riots collected by G. Rudé. ${ }^{1}$

The authorities were completely in control by the $23 \mathrm{rd}$ and started to dismiss some of their men. The Artillery Company were dismissed on the 25th and the Light Horse Volunteers were dismissed on the 24th. The Mayor felt that the Light Horse Volunteers had played a very significant part in dealing with the mobs and wrote to Colonel Herries, thanking him for "the readiness and alacrity in which this respectable corps turned out at my request! .... for the spirit and gallantry you have displayed during the whole of the service especially for the resolution and firmness with which on Wednesday night, you stood the attack, and checked the progress of a lawless mob at Moorfields and thereby saved the Eastern part of the Metropolis, at least, from riot and desolation." In Shoe Lane and Fleet Street he praised the "gallant and generous manner used to suppress the daring attempts of these abandoned wretches who aimed at the overthrow of law and government". ${ }^{2}$ The Light Horse had in fact proved one of the most useful of the Volunteer bodies in turning out so quickly, while some of the recently formed foot volunteer bodies were rather slow in assembling. A considerable burden had fallen on the regular troops, the use of whom was not popular in the City of London. Too often the behaviour of the troops seems to have irritated the prickly regard for the City liberties. Jealous of their private jurisdiction, the city authorities tried to limit the use of the regulars to the minimum and it was often in a tone of regret that their help was solicited. In the letter of thanks to the Home Office for the efforts of the Guards, there is at least a hint of tolerant surprise at the good behaviour of the Guards, and after each report in to the Home Office the Mayor repeated the formula that the troops were behaving with moderation and respect. The Mayor was pleased to report that: "they have not done the smallest injury to any human body, not so much as the hair of a child's head has been hurt by them, they behaved when on duty in the streets with the utmost temper, patience and moderation, thus were not frightened by the threats or number of the rioters nor to be provoked by insults or otherwise from that strict line of forebearance enjoined them by their Com-

$1 \mathrm{G}$. Rudé has pioneered the research into the moderation of crowd behaviour in riots, a precise statement of his views is in The Crowd in History, especially pp. 254-7.

2 Lord Mayor to Col. Herries, 24th August, 1794, HO 50.339. 
manders and as to their conduct within the Mansion House which was their quarters on the second and third night, I need only mention what is said by all my servants that they behaved like lambs." 1

The other arm of the authorities, the Special Constables, were well used in every capacity during the riots. Hundreds were sworn in and Colquhoun gives a picture of the rallying of support to the authorities which the special constables permitted. He claimed to have 500 respectable householders sworn in and claimed: "I attend at the different churches for that purpose and never fail to impress upon their minds the necessity of checking the circulation of hand-bills or seditious or inflammatory papers, and as they are situated in every quarter so that nothing can happen without them knowing."2 On the whole the constables proved remarkably successful even in dealing with quite large mobs such as the one at Battle Bridge.

The authorities after the initial hesitation managed to co-ordinate their forces quite well. The Home Office acted as the central headquarters to which reports were made and from which orders were sent out to the public offices and to the Mansion House. The Mayor had the most responsible of the positions "in the streets" and he seems to have adopted a fairly tolerant attitude at first, trying to reason with the mob to get them to disperse. Eventually he was forced into reading the riot act and from then on he was simply the most important magistrate, disposing of the forces of order as he saw fit and deciding on tactics with a great deal of freedom. P. Colquhoun was the most informative of the magistrates, writing a stream of reports to the Home Office and seemingly doing a great deal to quell the riots.

The number of convictions and indeed of arrests was quite small from nearly a week of rioting. One explanantion of this lies in the nature of the swiftly moving marauding band of rioters who melted away at the end of the evening or more often simply passed out of the City and away from the Mayor's jurisdiction. Unless he happened to have cavalry to take after them he was powerless. Nonetheless some were taken. But the Mayor was selective in his policy of committal. On the 24th he reported: "I have been tender about committing, thinking that the best thing for the public service was to reserve a few strong cases such as a jury would not in conscience overlook and to overlook everyone of these where there was a possibility of a doubt or a likelihood of an acquittal. If therefore the merits of the city magistrates in quelling the late riots shall be estimated by the number of convictions they will fall very short of the county magistrates." The problem

1 Lord Mayor to J. King, 24th August, 1794, HO 42.33.

2 P. Colquhoun to W. Wickham, 23rd August, 1794, HO 42.33. 
of securing a conviction from the London juries in fact bedevilled any attempt at widespread arrests. The ease with which alibis could be obtained and the difficulties of reliable identification of rioters also deterred the magistrates; it was also not easy to deal with men arrested in the heat of riot as the mob frequently tried to rescue them from the watch-houses. ${ }^{1}$

In the end 23 were committed for trial after a preliminary examination, of these the records survive for 16 . Four tried at the Old Bailey received death sentences. These were Joseph Strutt, indicted for riotously and unlawfully assembling to pull down the King's Arms of William Oastliff on the 17th. Strutt was reported to have kept repeating "We will be in" and in defence claimed to have been drunk and carried along by the mob. An officer, Henry Moreland, who helped drive the mob back at cutlass point, said Strutt kept rallying the mob. Anthony Warnbeck and Richard Purchase were tried for the offence at the house of Robert Layzell on the 20th. Thomas Osborne and Thomas Biggot were indicted for the same offence at Luke Case's house. Biggot was found guilty, while Osborne had an alibi. Five were indicted for disturbing the peace and trying to demolish the Old Sash in Moorfields of Wheeler. Though one of them was found on the premises the next morning, they were all released for lack of firm eye witnesses. At the Westminster Assizes several people received lighter sentences. A woman was put in Newgate for a month for riot and assault. John Gordon, on a charge of riot and assault and found guilty of the latter, was sent to sea. Three others received a month in prison on the same charge. Three others were indicted for riotous assembly but the relevant session role has been lost. ${ }^{2}$

Unfortunately these records tell us very little about the rioters of 1794. Hardly any gave their occupation in any detail and we are left with the usual problem of whether the convicted are a representative sample of the rioters. Here the number we have evidence on is so small that little can be said, other than that the ages of the four condemned to death were $34,21,18$ and 17 years. The participation of the younger elements of the population bears out the findings of Rudé on London mobs. Though the four men capitally convicted described themselves as labourers, it would be unwise to generalise from this evidence about the involvement of the lower classes of the capital in the riots. ${ }^{3}$ One point can be made and that is that the riots occurred over a wide area.

1 Lord Mayor to J. King, 24th August, 1794, HO 42.33.

2 Old Bailey Proceedings for 1794, pp. 955-994; Westminster Sessions, October, 1794 ; Middlesex Sessions, September, 1794.

3 Preparation of the case versus the rioters, Treasury Solicitor's Papers, TS 11.4500. 
Charing Cross and the Golden Lane area are over two miles apart, yet there was sufficient homogeneity in feeling across the capital for the original incident to spark off riots at that distance. There is no evidence that the Charing Cross mob moved to Golden Lane, rather it seems that the disturbances in the Golden Lane area were the work of mobs who retreated from the City after they had done their work. Again this rapidly moving mob, invading the borders of the City of London and retreating is familiar from other studies of the London mob. The riots of 1794 were not the last time that the London mob vented its fury on the "crimp" or recruiting houses. They were attacked in the summer of 1795, during demonstrations against the war and the high-price of food. But the riots of 1794 occurred against a background of stable prices in a situation which demands explanation from other sources than economic distress. The 1794 disturbances seem in the main to have been the outcome of rumour during a period of intense recruitment, revealing the latent fears and hostility of the populace towards the armed forces. Just as the price of bread could exercise a tyranny over the poorest inhabitants of the cities and towns, the prospect of being snatched from home and family by press-gangs or "crimps" was a constant dread in wartime for the poorer inhabitants of the capital. In the summer of 1794 the rumours signified a state of anxiety amongst some sections of the community and one incident was sufficient to trigger off the anger of the mob.

These riots were also the largest to occur in London since the Gordon Riots of 1780 in terms of duration and scale. They illustrated that at least one consequence of the French Revolution was the attempt by certain groups, especially the radical societies, to influence disorders in an insurrectionary direction. Thus the authorities were forced to reappraise the agencies of public order, they could see that the armed Associations and the Police Offices had acquitted themselves creditably. It was on these that they were to rely through the rest of the seventeennineties to contain traditional disorder and the threat of revolutionary insurrection in the capital. 